thành công lần hai.

1 trường hợp ghi nhận có biểu hiện thiếu máu hoại tử ổ loét cạnh khổi u vùng tá tràng khi nội soi sau nút mach, sau đó đã được loại bỏ khối u kèm ổ tổn thương vùng tá tràng bằng phẫu thuật. Bệnh nhân được nút chặn các nhánh trong vòng nối tá tụy và động mạch vị tá tràng bằng coils và nút tắc bằng keo sinh học NBCA. Tỷ lệ gây thiếu máu ruột sau nút động mạch vùng tá tụy là thấp do sự phong phú của hệ thống tưới máu khu vực này. Trường hợp này có thể giải thích do ổ loét lớn chiếm $1 / 2$ chu vi lòng tá tràng, sau nút rộng tãi động mạch vị tá tràng và vòng nối tá tụy nên có dấu hiệu thiếu máu hoại tử.

Nghiên cứu này vẫn còn nhiều hạn chế. Trước hết, số lượng $\mathrm{BN}$ trong nghiên cứu còn nhỏ, chưa mang tính đại diện cho quần thể, các số liệu còn đơn giản, mang tính mô tả. Hơn nữa, nghiên cứu này có thời gian theo dõi ngắn và mới chỉ đề cập tới các biến chứng cấp tính mà chưa đánh giá được các biến chứng và di chứng xa sau điều trị. Những nghiên cứu với số lượng cõ̃ mẫu lớn hơn, thời gian theo dõi dài hơn, so sánh ngẫu nhiên có đối chứng cần được thực hiện để đánh giá chi tiết hơn về tính an toàn, hiệu quả của phương pháp này.

\section{KẾT LUÂN}

Kết quả nghiên cứu cho thấy can thiệp nút mạch là phương pháp hiệu quả và an toàn có thể thực hiện cho những trường hợp chảy máu tá tràng đã̉ thất bại với điều trị nội khoa và nội soi cầm máu.

\section{TÀI LIÊU THAM KHẢO}

1. Mille $M$, Engelhardt $T$, Stier A. Bleeding Duodenal Ulcer: Strategies in High-Risk Ulcers. Visc Med. 2021;37(1):52-62. doi:10.1159/000513689

2. Loffroy $R$, Favelier $S$, Pottecher $P$, et al. Transcatheter arterial embolization for acute nonvariceal upper gastrointestinal bleeding: Indications, techniques and outcomes. Diagnostic and Interventional Imaging. 2015;96(7-8):731744. doi:10.1016/j.diii.2015.05.002

3. Hà Văn Quyết. Chảy máu đường tiêu hóa. In: Bệnh Học Ngoại Dùng Cho Sau Đại Học Tập I. Nhà xuất bản y hoc; 2006:36-37.

4. Loffroy $\mathbf{R}$, Guiu B, $\mathbf{D}^{\prime}$ Athis $\mathbf{P}$, et al. Arterial Embolotherapy for Endoscopically Unmanageable Acute Gastroduodenal Hemorrhage: Predictors of Early Rebleeding. Clinical Gastroenterology and Hepatology. doi:10.1016/j.cgh.2009.02.003

5. Madhusudhan KS, Venkatesh HA, Gamanagatti S, Garg P, Srivastava DN. Interventional Radiology in the Management of Visceral Artery Pseudoaneurysms: A Review of Techniques and Embolic Materials. Korean J Radiol. 2016;17(3):351-363. doi: $10.3348 /$ kjr.2016.17.3.351

6. De Wispelaere JF, De Ronde T, Trigaux JP, de Cannière L, De Geeter $\mathbf{T}$. Duodenal ulcer hemorrhage treated by embolization: results in 28 patients. Acta Gastroenterol Belg. 2002;65(1):6-11.

7. Kuyumcu G, Latich I, Hardman R, Fine G, Oklu R, Quencer K. Gastrodoudenal Embolization: Indications, Technical Pearls, and Outcomes. JCM. 2018;7(5):101. doi:10.3390/jcm7050101

8. Zhou T-Y, Sun J-H, Zhang Y-L, et al. Postpancreaticoduodenectomy hemorrhage: DSA diagnosis and endovascular treatment. Oncotarget. 2017;8(43):73684-73692.

doi:10.18632/oncotarget. 17450

\title{
ĐÁNH GIÁ TÍNH ĐÔNG NHẤT VÀ Đô ỔN ĐINH MẪU HBV DNA ĐÔNG KHÔ THEO TIÊU CHUẨN VỀ MẪU NGOẠI KIỂM
}

\section{TÓM TẮT}

Mục tiêu: Xây dựng quy trình sản xuất mẫu HBV DNA đông khô sử dựng trong ngoại kiểm. Đánh giá tính đồng nhất và độ ổn định của mẫu huyết tương HBV DNA đông khô sau sản xuất. Phương pháp

\footnotetext{
${ }^{1}$ Đai hoc Y Dướ TP.HCM

2Bềnh viên Đai hoc Y Dước TP.HCM

${ }^{3}$ Trung tâm Kiểm chuân chất lượng Y học - Đại học Y Dướ TP.HCM

Chịu trách nhiệm chính: Vũ Quang Huy

Email: drvuquanghuy@gmail.com

Ngày nhận bài: 29.7.2021

Ngày phản biên khoa hoc: 27.9.2021

Ngày duyệt bài: 1.10.2021
}

\section{Vũ Quang Huy ${ }^{1,2,3}$, Trần Thị Mỹ Qui ${ }^{1}$}

nghiên cứu: Nghiên cứu thực nghiêm trên các mẫu huyết tương dương tính HBV DNA, đánh giá tính đồng nhất và độ ổn định của mẫu huyết tương HBV DNA đông khô bằng kiểm đinh so sánh môt trung bình (Oneway ANOVA) và phép kiểm T- test. Kết quả: Mẫu huyết tương HBV DNA đông khô với 3 mức nồng độ đạt tính đồng nhất, độ ổn định vận chuyển trong 7 ngày. Mẫu đat độ ổn đỉnh bảo quản tai nhiệt đô $-20^{\circ} \mathrm{C}$ lên đến 150 ngày, ở nhiệt độ $2-8^{\circ} \mathrm{C}$ trong 90 ngày, ở nhiệt độ $25^{\circ} \mathrm{C}$ và $37^{\circ} \mathrm{C}$ trong 10 ngày (giá trị $p>$ 0.05). Kết luận: Quy trình sản xuất mẫu HBV DNA đông khô đã được xây dựng thành công. Tính đồng nhất và độ ổn định của các mẫu được sản xuất đáp ứng các tiêu chí của tiêu chuẩn ISO 13528:2015 và ISO guide 35. Tư khóa: Đánh giá, HBV DNA, huyết tương đông khô. 


\section{SUMMARY}

\section{EVALUATION OF HOMOGENEITY AND STABILITY OF HBV-DNA SAMPLE BY} STANDARDS OF PROFICIENCY TEST ITEMS

Objectives: Development of a production process for lyophilized HBV DNA samples used in proficiency testing. Evaluation of the homogeneity and stability of HBV DNA lyophilized samples after production. Methods: Experimental research on HBV DNA positive plasma samples, evaluate the homogeneity and stability of lyophilized HBV DNA plasma samples by an average comparison test (Oneway ANOVA) and T-test. Result: Lyophilized HBV DNA plasma samples with three levels of concentration achieved homogeneity and stability in transporting for 7 days. Samples achieved storage stability at $-20^{\circ} \mathrm{C}$ for up to 150 days, at $2-8^{\circ} \mathrm{C}$ for 90 days, at $25^{\circ} \mathrm{C}$ and $37^{\circ} \mathrm{C}$ for 10 days ( $p$ value $>0.05$ ). Conclusion: The procedure of lyophilized HBV DNA sample production has been successfully developed. The homogeneity and stability of produced samples meet the criteria standard of ISO 13528:2015 and ISO guide 35.

Keywords: Evaluate, HBV DNA, lyophilized HBV DNA plasma.

\section{I. ĐĂT VẤN ĐỀ}

Viêm gan siêu vi $B$ là bệnh truyền nhiễm quan trọng, mang tính chất toàn câu do siêu vi $B$ (HBV) gây ra. Theo báo cáo của Tổ chức Y tế Thế giới, năm 2015 ước tính khoảng 257 triệu người nhiễm viêm gan siêu vi $B$ mạn và 884.400 tử vong do các biến chứng xơ gan và ung thư biểu mô tế bào gan[6]. Tại Việt Nam, theo khảo sát trên 29,775 người dân sống tại thành phố Hồ Chí Minh có tỉ lệ $\mathrm{HBsAg}$ dương tính là 9.1\%[2]. Xét nghiệm HBV DNA là một xét nghiệm quan trọng trong việc phát hiện và theo dõi điều trị bểnh nhân nhiễm viêm gan siêu vi B. Quản lý chất lượng xét nghiệm HBV DNA là rất cần thiết đối với bất kỳ một cơ sở xét nghiệm nhằm cung cấp các kết quả chính xác, kịp thời đến khách hàng. Ngoai kiểm đước xem như môt công cu hữu hiệu trong việc kiểm soát chất lượng xét nghiệm, giúp đánh giá một cách khách quan, xem xét và khắc phục các sai số kịp thời.

Từ năm 2017, Tại Trung Tâm Kiểm Chuẩn Chất Lượng Xét Nghiệm Y Học - Đại Học Y Dược Thành Phố Hồ Chí Minh đã nghiên cứu xây dựng quy trình sản xuất mẫu ngoại kiểm định lượng HBV DNA bằng phương pháp đông lạnh và đã được áp dụng vào chương trình ngoại kiểm của Trung tâm[3]. Nhằm nâng cao chất lượng, tăng tính ổn định của mẫu ngoại kiểm, chúng tôi nghiên cứu áp dụng kỹ thuât đông khô vào sản xuất mẫu giúp mẫu dễ dàng vận chuyển, bảo quản và lưu giữ trong thời gian dài. Xuất phát từ thực tiễn trên, chúng tôi tiến hành nghiên cứu
"Đánh giá tính đồng nhất và độ ổn định mẫu HBV DNA đông khô theo tiêu chuẩn về mẫu ngoại kiểm".

Mục tiêu nghiên cứu: Xây dựng quy trinh sản xuất mẫu HBV DNA đông khô sư dụng trong ngoại kiểm. Đánh giá tính đồng nhất của mẩu huyết tương HBV DNA đông khô. Đánh giá độ ổn định vận chuyển và độ ổn định bảo quản của mẫu huyêt tương HBV DNA đông khô theo thời gian và nhiệt độ.

\section{II. ĐỐl TƯƠNNG VÀ PHƯƠNG PHÁP NGHIÊN CỨU}

Đối tượng nghiên cứu: Các mẫu huyết tương HBV-DNA được sản xuất tại Trung tâm Kiểm chuẩn Chất lượng Xét nghiệm Y học - Đại học Y dược Thành phố Hồ Chí Minh.

Địa điểm: Trung tâm Kiểm chuẩn Chất lượng Xét nghiệm Y học - Đại học Y dược Tp.HCM (Đạt ISO 9001-2015 do tổ chức AJA Anh Quốc, ISO/IEC 17043:2010).

Thời gian nghiên cứu: tháng 10/2020 đên tháng 6/2021.

Tiêu chuẩn chọn mẫu: Thu thập mẫu huyết tương có nồng độ HBV DNA >7 ( $\log _{10}$ copies $/ \mathrm{mL}$ ) từ túi máu được sàng lọc tai bệnh viện Truyền Máu - Huyết học TP.HCM. Mẩu đã được qua sàng lọc không có sự hiện diện của kháng thể kháng HIV1/2, kháng thể HCV.

\section{Phương pháp nghiên cứu}

Thiết kế nghiên cứu: Nghiên cứu thực nghiệm

Tạo 3 lô mẫu dựa trên mức nồng độ $\mathrm{HBV}$ DNA có ý nghĩa quyết định lâm sàng theo hướng dẫn chẩn đoán và điều trị viêm gan siêu vi $B$ [1]:

- Lô $\mathrm{A}$ : nồng độ $\mathrm{HBV}$ DNA từ 6.0 - $7.0\left(\log _{10}\right.$ copies/mL).

- Lô B: nồng độ HBV DNA từ 4.0 - $5.0\left(\log _{10}\right.$ copies/mL).

- Lô C: nồng độ HBV DNA dưới ngưỡng phát hiện.

Đánh giá độ đồng nhất bằng cách chọn 10 mẫu ngẫu nhiên trong một lô, kiểm tra nồng độ lặp lại 2 lần sử dụng phép kiểm oneway ANOVA và T-test.

Đánh giá độ ổn định bằng cách chọn ngẫu nhiên 3 mấu trong một lô tại một thời điểm đánh giá, kiểm tra nồng độ lặp lại 2 lần, sử dụng phép kiểm T- Test.

- Ổn định vận chuyển: thiết kế theo môi trường vận chuyển với 3 lớp tương ứng: lo đông khô $3 \mathrm{~mL}$, hộp giấy chứa mẫu, hộp nhựa có nắp đậy; hộp mẫu được đặt vào thùng xốp có chứa 10 túi đá gel và được dán kín, sau đó được đánh giá tại các thời gian 3 ngày, 4 ngày, 5 ngày, 6 ngày, 7 ngày.

• Ổn định theo nhiệt độ bảo quản: Ở nhiệt độ 
$-20^{\circ} \mathrm{C}$ tại các thời điểm 30 ngày, 60 ngày, 90 ngày và 150 ngày; ở nhiệt độ $2-8^{\circ} \mathrm{C}$ tại các thời điểm 30 ngày, 60 ngày, 90 ngày; ở nhiệt độ $25^{\circ} \mathrm{C}$ và $37^{\circ} \mathrm{C}$ tại thời điểm 10 ngày.

Cỡ mẫu: Theo hướng dẫn của tiêu chuẩn ISO 13528: 2015 và ISO guide 35: 2006.

Tính đồng nhất 10 mấu/lô; đánh giá trên lô A, lô $\mathrm{B}$, lô C: $10 \times 3$ (lô) = 30 mẫu.

Độ ổn định 3 mẫu/lô/thời điểm; đánh giá trên lô A, lô B:

- Độ ổn định vận chuyển: 3 (mẫu) x 2 (lô) x 5 (thời điểm) = 30 mẫu.

- Độ ổn định theo nhiệt độ bảo quản: 3 (mẫu) $\times 2$ (lô) $\times 9$ (thời điểm) = 54 mẫu.

Cỡ mẫu được tính cho cả quy trình nghiên cứu: $n=30+30+54=114$ mẫu.

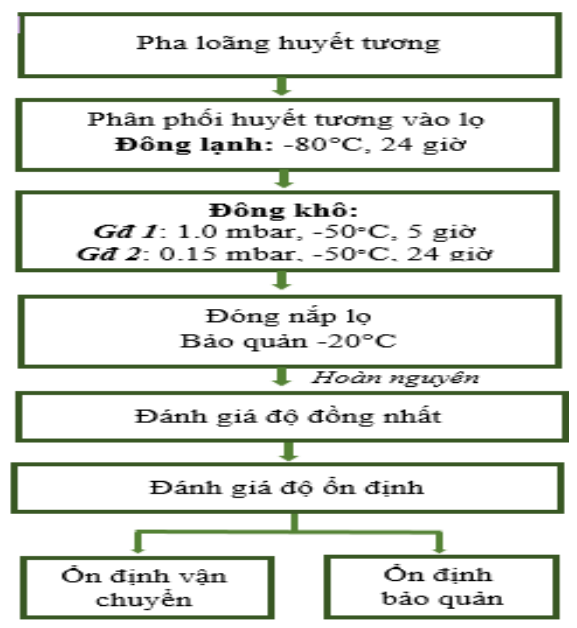

Hình 1: Sơ đồ quá trinh sản xuât và đánh giá mẫu HBV-DNA đông khô

Kỹ thuật xét nghiệm: Định lượng nồng độ HBV-DNA bằng phương pháp realtime PCR trên máy Eppendorf realplex 4.
Quy trình sản xuất và đánh giá HBV DNA đông khô

Bước 1: Pha loãng mẫu huyết tương HBVDNA theo nồng đô yêu cầu

Lô $A$ : nồng độ HBV DNA từ 6.0 - $7.0\left(\log _{10}\right.$ copies/mL).

Lô $B$ : nồng độ HBV DNA từ 3.8 - $5.0\left(\log _{10}\right.$ copies $/ \mathrm{mL}$ ).

Lô C: nồng độ HBV DNA dưới ngưỡng phát hiện

Bước 2: Cho $1000 \mu \mathrm{L}$ mẫu vào lọ đông khô $3 \mathrm{~mL}$, đăt vào tủ âm $-80^{\circ} \mathrm{C}$ trong 24 giờ.

Bước 3: Chuyển các mẫu huyết tương HBV DNA đã đông lạnh vào máy đông khô, cài đặt chương trình đông khô với 2 giai đoạn sấy. Giai đoạn 1 áp suất $1.00 \mathrm{mbar}$ và giai đoạn 2 áp suất $0.15 \mathrm{mbar}$. Duy trì nhiệt độ buồng sây ở $-50^{\circ} \mathrm{C}$.

Bước 4: Tiến hành đóng nắp các lọ mẫu đã đông khô và bảo quản tại nhiệt độ - $20^{\circ} \mathrm{C}$.

Bước 5: Đánh giá tính đồng nhất của mẫu HBV-DNA đông khô.

Bước 6: Đánh giá độ ổn định vận chuyển và độ ổn định bảo quản của mẫu huyết tương HBVDNA đông khô theo hướng dẫn ISO 13528 và ISO guide 35 .

Phân tính dữ liệu: Dữ liệu được thu thập và xử lý thống kê bằng phần mềm Microsoft Excel 2016 và Stata 14.

\section{KẾT QUẢ NGHIÊN CứU}

Sau khi hoàn tất quá trình đông khô, tiến hành hoàn nguyên mỗi mầu với $1000 \mathrm{~mL}$ nước cất khử nucleotide. Dung dịch sau hoàn nguyên được phân tích nồng độ HBV DNA bằng kỹ thuật RealtimePCR. Tính đồng nhất của mỗi lô mẫu được kiểm tra qua việc chọn ngẫu nhiên 10 mẫu trên lô và được phân tích lặp lại 2 lân. Kết quả đánh giá độ đồng nhất được thể hiện trong bảng 1.

Bảng 1: Kêt quả đánh giá độ đồng nhất của lô A, lô B, lô C $\left(\log _{10}\right.$ copies/mL)

\begin{tabular}{|c|c|c|c|c|c|c|c|c|c|c|c|}
\hline \multirow{2}{*}{ STT } & \multicolumn{4}{|c|}{ Lô A } & \multicolumn{4}{|c|}{ Lô B } & \multicolumn{3}{|c|}{ Lô C } \\
\hline & Lần 1 & Lần 2 & TB2 & & Lần 1 & Lần 2 & TB2 & \multirow{4}{*}{ 足 } & Lần 1 & Lần 2 & TB2 \\
\hline 1 & 6.68 & 6.82 & 6.75 & & 4.11 & 4.12 & 4.12 & & $\mathrm{~N} / \mathrm{A}$ & $\mathrm{N} / \mathrm{A}$ & - \\
\hline 2 & 6.82 & 6.72 & 6.77 & & 4.20 & 3.99 & 4.10 & & N/A & N/A & - \\
\hline 3 & 6.89 & 6.63 & 6.76 & & 3.98 & 4.25 & 4.12 & & N/A & N/A & - \\
\hline 4 & 6.92 & 6.73 & 6.83 & \multirow{3}{*}{ 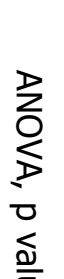 } & 4.22 & 4.08 & 4.15 & \multirow{2}{*}{ 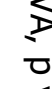 } & $\mathrm{N} / \mathrm{A}$ & N/A & - \\
\hline 5 & 6.71 & 6.86 & 6.79 & & 4.32 & 4.04 & 4.18 & & $\mathrm{~N} / \mathrm{A}$ & N/A & - \\
\hline 6 & 6.85 & 6.96 & 6.91 & & 4.23 & 4.17 & 4.20 & \multirow{5}{*}{ 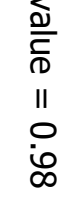 } & N/A & N/A & - \\
\hline 7 & 6.82 & 6.79 & 6.81 & \multirow{4}{*}{$\begin{array}{l}\widetilde{D} \\
\text { II } \\
0 \\
\infty \\
+\infty\end{array}$} & 4.08 & 4.15 & 4.12 & & N/A & N/A & - \\
\hline 8 & 6.63 & 6.80 & 6.72 & & 4.19 & 4.14 & 4.17 & & N/A & N/A & - \\
\hline 9 & 6.77 & 6.87 & 6.82 & & 4.08 & 4.31 & 4.20 & & N/A & N/A & - \\
\hline 10 & 6.77 & 6.83 & 6.80 & & 4.12 & 4.19 & 4.16 & & N/A & N/A & - \\
\hline TB10 & 6.79 & 6.80 & - & & 4.15 & 4.14 & & & - & - & - \\
\hline SD & 0.11 & 0.09 & $\begin{array}{ll}- \\
-\end{array}$ & & 0.10 & 0.09 & & & - & - & - \\
\hline
\end{tabular}


TB2: trung bình kết quả của 1 mấu ở 2 lần chạy; TB10: trung bình kết quả của 10 mấu ở lần chạy 1 hoặc lần chạy 2; SD: độ lệch chuẩn của 10 mẫu ở lần chạy 1 hoặc lần chạy 2.

N/A: kết quả dưới ngưỡng phát hiện.

Nhận xét: Theo bảng 1 , nồng độ các mẫu trong cùng một lô của lô $A$ và lô $B$ đều đạt tính đồng nhất với giá trị $p$ tương ứng là $0.84,0.98$. Tất cả 10 mẩu lô $C$ đều có kết quả dưới ngưỡng phát hiện (NA).

Tiến hành đánh giá độ ổn định vận chuyển và độ ổn định bảo quản với các mẫu thuộc lô $A$, lô $B$. So sánh sự khác biệt về nồng độ HBV DNA ở tại thời điểm đánh giá với số liệu đánh giá tính đồng nhất. Kết quả được thể hiện trong các bảng 2, bảng 3.

Bảng 2: Đánh giá độ ổn định vận chuyển đôî với các mẫu lô A và lô B (logio copies/mL)

\begin{tabular}{|c|c|c|c|c|c|c|c|c|}
\hline \multirow{2}{*}{$\begin{array}{l}\text { Thời } \\
\text { điểm }\end{array}$} & \multicolumn{4}{|c|}{ Lô A } & \multicolumn{4}{|c|}{ Lô B } \\
\hline & Lần 1 & Lân 2 & Trung bình & $P$ value & Lần 1 & Lần 2 & Trung bình & $P$ value \\
\hline 0 ngày* & 6.80 & 6.80 & 6.80 & \multirow{6}{*}{$>0.05$} & 4.15 & 4.15 & 4.15 & \multirow{6}{*}{$>0.05$} \\
\hline 3 ngày & 6.83 & 6.77 & 6.80 & & 4.14 & 4.18 & 4.16 & \\
\hline 4 ngày & 6.77 & 6.82 & 6.80 & & 4.13 & 4.17 & 4.15 & \\
\hline 5 ngày & 6.78 & 6.83 & 6.81 & & 4.14 & 4.14 & 4.14 & \\
\hline 6 ngày & 6.84 & 6.79 & 6.82 & & 4.16 & 4.19 & 4.18 & \\
\hline 7 ngày & 6.79 & 6.78 & 6.79 & & 4.13 & 4.16 & 4.15 & \\
\hline
\end{tabular}

Lần 1/ Lần 2: Trung bình nồng độ chạy lần 1/ lần 2 của 3 mấu được chọn ngấu nhiên tại các thời điểm. 0 ngày*: trung bình nồng độ được thu thập từ đánh giá tính đồng nhất.

Nhận xét: Theo bảng 2, tất cả các mẩu đánh giá thuộc lô $A$, lô $B$ đều đạt độ ốn định trong môi trường vận chuyển đến 7 ngày khi giá trị $p>0.05$.

Bảng 3: Đánh giá độ ổn định bảo quản mẫu đối với các mẫu lô $A$, lô $B$ (log $\log _{10}$ copies $/ \mathbf{m L}$ )

\begin{tabular}{|c|c|c|c|c|}
\hline \multirow{2}{*}{$\begin{array}{c}\text { Nhiệt } \\
\text { độ }\end{array}$} & \multirow{2}{*}{$\begin{array}{l}\text { Thời } \\
\text { gian }\end{array}$} & \multicolumn{2}{|c|}{$\begin{array}{c}\text { Trung bình } \\
\text { nông độ }\end{array}$} & \multirow{2}{*}{$\begin{array}{c}\text { T- } \\
\text { test }\end{array}$} \\
\hline & & Lô A & Lố B & \\
\hline & 0 ngày* & 6.80 & 4.15 & \multirow{10}{*}{ 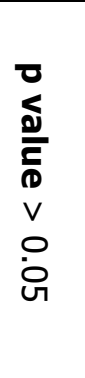 } \\
\hline $37^{\circ} \mathrm{C}$ & 10 ngày & 6.79 & 4.15 & \\
\hline $25^{\circ} \mathrm{C}$ & 10 ngày & 6.81 & 4.16 & \\
\hline \multirow{3}{*}{$2-8^{\circ} \mathrm{C}$} & 30 ngày & 6.81 & 4.17 & \\
\hline & 60 ngày & 6.80 & 4.14 & \\
\hline & 90 ngày & 6.81 & 4.16 & \\
\hline \multirow{4}{*}{$-20^{\circ} \mathrm{C}$} & 30 ngày & 6.82 & 4.18 & \\
\hline & 60 ngày & 6.81 & 4.17 & \\
\hline & 90 ngày & 6.79 & 4.16 & \\
\hline & 150 ngày & 6.78 & 4.14 & \\
\hline
\end{tabular}

Nhận xét: Theo bảng 3, nồng độ các mẫu thuộc lô $A$, lô $B$ đều đạt độ ổn định khi bảo quản ở nhiệt độ $37^{\circ} \mathrm{C}$ trong 10 ngày; ở $25^{\circ} \mathrm{C}$ trong 25 ngày; ở $2-8^{\circ} \mathrm{C}$ trong 90 ngày; ở $-20^{\circ} \mathrm{C}$ trong 150 ngày khi tất cả giá trị $\mathrm{p}>0.05$.

\section{BÀN LUÂ̂N}

Dựa theo tiêu chuẩn ISO 13528:2015 [5], nhà sản xuất trước mỗi lô mẫu gửi đến các đơn vị tham gia phải được đánh giá độ đồng nhất thông qua việc lấy ngẫu nhiên $10 \%$ số lượng mẫu sản xuất hoặc tối thiểu 10 mẫu để đánh giá. Nghiên cứu cho thấy, khi so sánh trung bình kết quả nồng độ HBV-DNA của 10 mẫu ở lần chạy 1 với trung bình nồng độ 10 mẫu ở lần chạy 2 không

có sự khác biệt ( $T$ - test, $p$ value $>0.05$ ). Đồng thời so sánh trung bình kết quả 2 lần chạy giữa 10 mẫu với nhau không có sự khác biệt (ANOVA, $p$ value $>0.05$ ). Như vậy, nghiên cứu đã kết luận mẫu đông khô sản xuất là hoàn toàn đồng nhất và có thể tiến hành đánh giá độ ổn định.

HBV DNA có bản chất là di truyền là DNA tương đối bền với nhiệt độ, tuy nhiên với điều kiện khí hậu nhiệt đới và độ ẩm cao như nước ta thì việc đánh giá độ ổn định vận chuyển của mẫu là hểt sức cân thiết. Chúng tôi thiết kế môi trường vận chuyển giả định tương tự vận chuyển mẫu thực tế, kết quả phân tích nồng độ HBVDNA mấu ổn định trong 7 ngày.

Nghiên cứu của chúng tôi chứng minh được độ ổn định của mẫu đông khô HBV-DNA tới 150 ngày khi bảo quản ở nhiệt độ $-20^{\circ} \mathrm{C} ; 90$ ngày ở nhiệt độ $2-8^{\circ} \mathrm{C}$ và 10 ngày ở các nhiệt độ $25^{\circ} \mathrm{C}$ hoặc $37^{\circ} \mathrm{C}$. Các giá trị $\mathrm{p}$ value thu được tại các thời điểm đánh giá ở 2 lô $A$ và lô $B$ đều lớn hơn 0.05 . Theo một nghiên cứu đánh giá độ ổn định mẫu chuẩn của WHO năm 2016, mẫu HBV DNA đông khô đạt ổn định lên đến 60 tháng ở nhiệt độ bảo quản $-20^{\circ} \mathrm{C}, 4^{\circ} \mathrm{C}, 20^{\circ} \mathrm{C}$ và ổn định tới 11 tuần ở nhiệt độ $37^{\circ} \mathrm{C}$ [7]]. So sánh với kết quả nghiên cứu sản xuất mẫu chuẩn quốc gia HBV DNA của Wang L.N và cộng sự, các mấu huyết tương HBV DNA ổn định ở $37^{\circ} \mathrm{C}$ ít nhất 1 tuần, mẫu bảo quản ở nhiệt độ môi trường $\left(20-25^{\circ} \mathrm{C}\right)$ trong vòng 2 tuần; mẫu bảo quản ở $2-8^{\circ} \mathrm{C}$ ổn định 6 tháng, và mấu bảo quản ở $-20^{\circ} \mathrm{C}$ thì ổn định hơn 2 năm. Kết quả nghiên cứu này hoàn 
toàn phù hợp với kết quả của hai nghiên cứu trên.

\section{KẾT LUẬN}

Mẫu HBV DNA đông khô được chúng tôi sản xuất đạt tính đồng nhất về nồng độ HBV DNA với kỹ thuât Realtime - PCR. Ngoài ra mẫu được đánh giá ổn định trong suốt quá trình vận chuyển lên đến 7 ngày và đạt độ ổn định bảo quản ở nhiệt độ $-20^{\circ} \mathrm{C}$ tới 150 ngày.

Từ những kết quả thí nghiệm và phân tích trên, chúng tôi đã xây dựng và hoàn thiện quy trình sản xuất mẫu huyết tương HBV DNA đông khô ứng dụng trong ngoại kiểm định lượng HBV DNA góp phần nâng cao chất lượng, đảm bảo tính chính xác của kết quả xét nghiệm.

\section{TÀI LIÊU THAM KHẢO}

1. Bộ Y tế (2019), Về việc ban hành hướng dẫn chẩn đoán, điêu trị bệnh viêm gan vi rút $\mathrm{B}$, trang 127 .

2. Vũ Quang Huy (2012), Khảo sát tình hình nhiễm Virus viêm gan $\mathrm{B}$ và chì số men gan trong cộng đồng tai một số khu vực thành phố Hồ Chí Minh, Tạp chí Y học thực hành (ISSN 1859-1663), TP. Hố
Chí Minh, trang 48-52.

3. Vũ Quang Huy (2017), Quy trình thử nghiêm sản xuất mầu ngoai kiểm định lượng HBV-DNA, Tap chí Y Học Tp. Hồ Chí Minh, TP. Hồ Chí Minh, trang 216-222.

4. International Organization for Standardization (2006), ISO Guide 35 Reference materials-general and statistical principles for certification, Geneva.

5. International Organization for Standardization (2015), ISO 13528:2015 Statistical methods for use in proficiency testing by interlaboratory comparisons, Geneva.

6. World Health Organization (2017), Global hepatitis report 2017.

7. World Health Organization (2016), WHO Expert Committee on Biological Standardization Collaborative study to evaluate the proposed WHO 4th International Standard for Hepatitis B Virus (HBV) DNA for Nucleic Acid Amplification Technique (NAT) based assays.

8. LN Wang, Wei Deng, ZY Shen, WX Chen, JM Li (2007) Establishment of the first national standards for nucleic acid amplification technology assay for HBV DNA, Chinese journal of hepatology, pp. 107-110.

\section{KHẢO SÁT TÌNH TRANG MÔ GÂN BẢO QUẢN TẠI LAB CÔNG NGHÊ MÔ GHÉP - TRƯỜ'NG ĐẠI HỌC Y HÀ Nô̂I GIAI ĐOẠN 2010 - 2020}

\section{TÓM TẮT}

Mục tiêu: Khảo sát tình trạng mô gân bảo quản tại Lab Công nghệ mô ghép - Trường Đại học Y Hà Nội giai đoạn 2010 - 2020. Phương pháp: Nghiên cứu hồi cứu, mô tả cắt ngang trên tất cả các mấu gân được bảo quản tại Lab công nghệ mô ghép - Trường Đai hoc Y Hà Nôi trong giai đoan từ năm 2010 - 2020. Kết quả: Có 2139 mâu mô gẩn được bảo quản trong đó có $2012(94,1 \%)$ mẫu đã được sử dụng. Tỉ lệ bảo quản gân Achille và gân bánh chè chiếm cao nhất 2 năm 2010 và 2011 (60\% và 32\%), nhưng giảm dân trong những năm gân đây (năm 2020 là 9,7\% và $4,3 \%$ ). Trong khi đó, gân cằng tay, từ năm 2010 và 2011 còn chưa được bảo quản tới năm 2020 tỷ lệ này tăng lên là $29,7 \%$. Gân cằng chân có sự tăng mạnh từ 4\% trong năm 2010 lên 56,2\% năm 2020 đặc biệt năm 2019 còn chiếm tới $80,9 \%$. Tỷ lê các loai mô gấn được sử dụng qua các năm có sự thay đổi lớn, gân Achille và gân bánh chè năm 2010 (64\% và $32 \%)$, năm 2011 (69,9\% và 18,5\%) có tỷ lệ được sử dụng

${ }^{1}$ Trường Đại học Kỹ thuật Y tế Hải Dương

${ }^{2}$ Trường Đại học Y Hà Nội

Chịu trách nhiệm chính: Nguyễn Thị Tân

Email: nguyentann91@gmail.com

Ngày nhận bài: 29.7.2021

Ngày phản biên khoa họ: 28.9.2021

Ngày duyệt bài: 4.10.2021

\section{Nguyễn Thị Tân ${ }^{1}$, Lê Thị Hồng Nhung²}

cao thì tới năm 2020 tỷ lệ này giảm đáng kể chỉ còn $6 \%$ gân Achille và $0 \%$ gẩn bánh chè được sử dụng. Trái lại, năm 2010 chỉ có $4 \%$ gân cẳng chân, chưa có gân cằng tay được sử dụng, thì tới năm 2020 tỷ lệ này lân lượt là $60,7 \%$ và $33,3 \%$. Kết luận: Trong giai đoan 2010 - 2020, các mấu mô gân đồng loai được bảo quản theo quy trình lạnh sâu tại Lab Công nghệ mô ghép - Trường đại học Y Hà Nôi khá đa dạng, nhiều loại mô gân được thu nhận, xử lý bảo quản và tỉ lệ sử dụng mô gân được sử dụng cao. Mô gân Achille và gân bánh chè bảo quản và sử dụng có xu hướng giảm, trong khi gân cằng tay và đặc biệt là gân cẳng chân ngày càng được bảo quản và sử dụng nhiêu do những thay đổi về quan điểm trong thực hành lâm sàng ngoại khoa.

Tư' khoá: Mô gân, Bảo quản mô, Ghép gân đồng loại

\section{SUMMARY}

INVESTIGATE THE REALITY OF TENDON TISSUE PRESERVATION IN TISSUE ENGINEERING LABORATORY - HANOI MEDICAL UNIVERSITY FROM 2010 TO 2020

Objectives: Investigate the reality of tendon tissue preservation in tissue engineering labotory Hanoi Medical University from 2010 to 2020. Methods: A cross-sectional descriptive study was taken from total tendon tissue which preserved in tissue engineering labotory - Hanoi Medical University form 2010 to 2020. Results: There were 2139 